\title{
Slaughter weights on animal performance, carcass commercial cuts and meat characteristics of cull cows
}

\section{Pesos de abate sobre o desempenho animal, cortes comerciais da carcaça e características da carne de vacas de descarte}

\author{
Regis Luis Missio ${ }^{1}$; João Restle ${ }^{2 *}$; José Luiz Moletta ${ }^{3}$; Fernando Kuss ${ }^{4}$; \\ José Neuman Miranda Neiva ${ }^{5}$; Denise Adelaide Gomes Elejalde ${ }^{6}$; \\ Ivan César Furmann Moura ${ }^{7}$; Ivanor Nunes Prado ${ }^{8}$; Fabrícia Rocha Chaves Miotto ${ }^{5}$
}

\begin{abstract}
This study aimed to evaluate the effect of slaughter weight on animal performance, carcass commercial cuts and meat characteristics of Purunã cows feedlot finished. We used 28 cull cows with $68.02 \pm 17.36$ months of age slaughtered at different weights $(461,476,434$ and $522 \mathrm{~kg})$. The experimental design was completely randomized with four treatments (slaughter weight) and seven replicates (animals). The dry matter intake, expressed as $\mathrm{kg} \mathrm{d}^{-1}$ and $\%$ of body weight, presented quadratic variation with increasing slaughter weight, with the highest values observed for slaughter weight of $461 \mathrm{~kg}$. The average daily gain decreased linearly, whereas the absolute weight of forequarter, short ribs, and pistol cut linearly increased by the advance of slaughter weight. In relative terms only the short ribs was changed by increase slaughter weight, increasing linearly. Between the proportions of meat cuts prepared for commercialization, linear increases were observed for the chuck and striploin. Increasing slaughter weight promoted linear increases in the scores of color, marbling and palatability, but did not alter the score of tenderness of the meat. The increase of slaughter weight of cull cows of the Purunã breed reduces animal performance, increasing the losses by trimming fat, with important benefits only for the meat palatability.
\end{abstract}

Key words: Fat trimming, meat tenderness, pistol cut, short ribs, weight gain

\section{Resumo}

Objetivou-se avaliar o efeito do peso de abate sobre o desempenho animal, cortes comerciais da carcaça e características da carne de vacas Purunã terminadas em confinamento. Foram utilizadas 28 vacas de

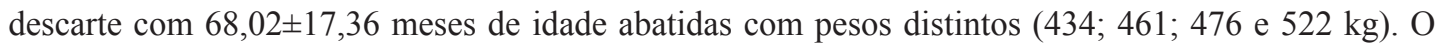

1 Prof., Dept ${ }^{\mathrm{o}}$ de Agronomia, Universidade Tecnológica Federal do Paraná, UTFPR, Pato Branco, PR, Brasil. E-mail: regisluismissio@gmail.com

2 Bolsista PVNS CAPES, Escola de Medicina Veterinária e Zootecnia, Universidade Federal do Tocantins, UFT, Araguaína, TO, Brasil. E-mail: jorestle@terra.com.br

3 Pesquisador, Instituto Agronômico do Paraná, IAPAR, Ibiporã, PR, Brasil. E-mail: moletta@iapar.br

4 Prof., Dept ${ }^{\circ}$ de Zootecnia, UTFPR, Dois Vizinhos, PR, Brasil. E-mail: fernandokuss@utfpr.edu.br

5 Profs., Escola de Medicina Veterinária e Zootecnia, UFT, Araguaína, TO, Brasil. E-mail: araguaia2007@gmail.com; fabriciarchaves@hotmail.com

6 Pós-Doutoranda, Programa de Pós-Graduação em Agronomia, UTFPR, Pato Branco, PR, Brasil. E-mail: denise.elejalde@gmail. com

7 Discente do Curso de Mestrado do Programa de Pós-Graduação em Zootecnia, UTFPR, Dois Vizinhos, PR, Brasil. E-mail: ivancesar.moura@bol.com.br

8 Prof., Dept ${ }^{\circ}$ de Zootecnia, Universidade Estadual de Maringá, UEM, Maringá, PR, Brasil. E-mail: inprado@uem.br

* Author for correspondence 
delineamento experimental foi o inteiramente casualizado com quatro tratamentos (pesos de abate) e sete repetições (animais). O consumo de matéria seca, expresso em $\mathrm{kg} \mathrm{dia}^{-1} \mathrm{e} \%$ do peso corporal, apresentou variação quadrática em função do avanço do peso de abate, sendo os maiores valores observados para o peso de abate de $461 \mathrm{~kg}$. O ganho de peso médio diário diminuiu linearmente, enquanto que o peso absoluto do dianteiro, ponta de agulha e traseiro especial aumentou linearmente com avanço do peso de abate. Em termos relativos somente a ponta de agulha foi alterada pelo avanço do peso de abate, aumentando linearmente. Entre as proporções dos cortes cárneos preparados para comercialização, elevações lineares foram verificadas para o acém e contra filé. $\mathrm{O}$ aumento do peso de abate promoveu incrementos lineares nos escores de coloração, marmoreio e palatabilidade, mas não alterou a maciez da carne. O avanço do peso de abate de vacas de descarte da raça Purunã reduz o desempenho animal, aumentando as perdas pelo recorte de gordura, com benefícios importantes apenas para a palatabilidade da carne.

Palavras-chave: Ganho médio diário, maciez, ponta de agulha, recorte de gordura, traseiro especial

\section{Introduction}

The slaughter of females represents a significant share of the flow monetary of the cattle production chain, which actually represents nearly $50 \%$ of the animals slaughtered in Brazil (ANUALPEC, 2014). The offer of cull cows from the breeding herd is inevitable, since at least $20 \%$ of cull cows are yearly substituted by heifers that have greater productive potential. The remaining slaughtered females include a quota of heifers, calculated to exceed the rate of replacement. The remaining females slaughtered is constituted by heifers that exceeds the replacement rate of cull cows, which represents the production of carcass and meat with quality since except for the carcass weight, the meat and carcass characteristics of heifers are similar to the young males (VAZ et al., 2010). It is worth noting, however, that while the cull cows for slaughter rate tends to decrease with increase in reproductive rates, the number of slaughtered heifers tends to increase due to the increase of the cattle herd as well as by rising the productive and reproductive indices with the improvement of the production systems.

Despite the downward trend of the cull cows slaughter rate with the intensification of production systems, the number of animals annually slaughtered in this category tends to remain high if considered the size of the Brazilian cattle herd, which is considered the world largest commercial herd with about 198.7 million heads (ANUALPEC, 2014). Lean cull cows availability, in this sense, meets the demand for feedlot animals, which indicates a reasonable acceptance by the systems of livestock finishing, because of its high bodily weight and potential for expressing elevated rates of weight gains and due to the possibility of compensatory weight gain expression, resulting in reduction of the finishing period and increased working capital.

Age, genotype, category, and slaughter weight are thus the main factors highlighted for efficient transformation of feed into meat, as well as for the characteristics of carcass and meats (DI MARCO, 1994). Thus, for the same genotype and/or category, slaughter weight is the foremost important aspect pertaining to quantity and proportion of body tissues at slaughter. For cull cows, a wide range of body tissues are already fully formed, and finishing timing is characterized by muscle mass recovery, bone density, and intense fat deposition (MISSIO et al., 2013a). Therefore, although the increase in slaughter weight favors characteristics that are of interest to industry (carcass weight and breaking when frozen) and consumer (marbling and palatability), feed efficiency is reduced because of the increase of body fat (RESTLE et al., 1996; ARBOITTE et al., 2004a; KUSS et al., 2005). Reduced feed efficiency is not favorable to farmers because it increases the production costs. Therefore, determining the best period for slaughtering is essential for attaining maximum productive efficiency during the livestock finishing stage and meeting the carcass and meat characteristics. This 
is even more relevant to Purunã breeders, for whom information concerning productive potential, and carcass and meat characteristics are incipient.

Considering the above, the present study aimed to evaluate the performance, carcass and meat characteristics of cull cows of the Purunã breed slaughtered with different weights.

\section{Materials and Methods}

A total of 28 cull cows of the Purunã breed (1/4 Aberdeen Angus, 1/4 Caracu, 1/4 Charolais and $1 / 4$ Canchim) from the experimental herd of the Instituto Agronômico do Paraná (IAPAR) were used. The average age of the cows was $68 \pm 17$ months. Prior to the experimental period, the cows were subjected to a period of mounting between September and December 2006. During this period, the animals were grazed on Hemarthria altissima 'Florida'. In February 2007, a gestational diagnosis was performed, and the cows with negative results were individually confined to semi-closed stalls with concrete flooring, and each given an individual feed trough and water supply. The first $14 \mathrm{~d}$ of the confinement period were dedicated to allowing the animals to adapt to diets and facilities. The animals were weighed at the start of the experimental period, then every $28 \mathrm{~d}$, after fasting for 14-16 h.

The experimental design was completely randomized, with four treatments (slaughter weights) and seven replicates (animals), in which the slaughter weights evaluated were 434, 461, 476, and $522 \mathrm{~kg}$, and the weights of the animals at the start of the experimental period were 381.6, 378.4, 384.0 and $379.1 \mathrm{~kg}$. Among the treatments, 30, 51,63 , and $105 \mathrm{~d}$ were required to reach slaughter weights of 434, 461, 476 and $522 \mathrm{~kg}$, respectively. The animals were fed daily (at 08:00 and 14:00), maintaining $10 \%$ leftovers. Consumption of nutrients was ascertained by daily registers of feed intake, which was determined by means of weighing foods and leftovers. The animals' diet (Table 1) was composed of corner silage, ground corn grains, oat bran, mineral supplement, and limestone. Corn silage was offered ad libitum, representing 58\% of the dry matter of the diet, while the concentrate was provided at a rate of $1.2 \%$ of the body weight of each animal, equivalent to $42 \%$ of the dry matter of the diet.

Table 1. Composition of the diet and ingredients.

\begin{tabular}{lcccccccccc}
\hline \multirow{2}{*}{ Item } & $\begin{array}{c}\text { Composition of diet } \\
\text { (\% of dry matter) }\end{array}$ & \multicolumn{8}{c}{ Composition of ingredients (\% of dry matter) } \\
\cline { 3 - 11 } & DM & DM & CP & NDF & ADF & EE & TC & NFC & TDN \\
\hline Corn silage & 58.00 & 35.84 & 3.06 & 5.66 & 43.60 & 26.84 & 2.13 & 89.15 & 45.60 & 60.58 \\
Grain corn & 73.00 & 89.37 & 1.24 & 7.67 & 21.90 & 13.08 & 4.80 & 86.29 & 64.41 & 81.75 \\
Soybean meal & 25.00 & 89.54 & 5.98 & 44.75 & 12.97 & 4.40 & 2.37 & 46.90 & 33.93 & 69.75 \\
Mineral core & 1.00 & 99.99 & 99.98 & -- & -- & -- & -- & -- & -- & -- \\
Limestone & 1.00 & 99.99 & 99.98 & -- & -- & -- & -- & -- & -- & -- \\
Diet & -- & 58.43 & 3.62 & 10,20 & 33,36 & 20,04 & 2,96 & 83,09 & 49,76 & 67,54 \\
\hline
\end{tabular}

Mineral core $=40 \mathrm{~g} \mathrm{~kg}^{-1}$ of $\mathrm{P}$ and $146 \mathrm{~g} \mathrm{~kg}^{-1}$ of $\mathrm{Ca} ;{ }^{1} \mathrm{DM}=$ dry matter $(\%$ of natural matter $)$; $\mathrm{MM}=$ mineral matter; $\mathrm{CP}=\mathrm{crude}$ protein; $\mathrm{NDF}=$ neutral detergent fiber; $\mathrm{ADF}=$ acid detergent fiber; $\mathrm{EE}=$ ether extract; $\mathrm{TC}=$ total carbohydrates; $\mathrm{NFC}=$ non-fibrous carbohydrates; TND $=$ total digestible nutrients.

Samples of food and leftovers were collected weekly to determine their chemical composition, which were pre-dried in an oven with air ventilation forced to $55^{\circ} \mathrm{C}$ for 72 hours and processed in a Wiley mill with $1 \mathrm{~mm}$ sieves. The dry matter, ash, crude protein and ether extract were determined according to AOAC (1990). The neutral detergent fiber (NDF) and acid detergent fiber (ADF) were determined according to Van Soest et al. (1991) and Van Soest (1973), respectively. The total carbohydrates (TC) 
and non-fiber carbohydrates (NFC) were determined according Sniffen et al. (1992), wherein: TC $=100$ $-(\% \mathrm{CP}+\% \mathrm{EE}+\mathrm{MM} \%)$ and $\mathrm{NFC}=\mathrm{TC}-\mathrm{NDF}$. The total digestible nutrient content was determined by Weiss (1993). The determination of the chemical composition of the diet was calculated from the chemical composition of foods.

The animals were slaughtered in a commercial slaughterhouse approved by the Brazilian Federal Inspection Service (Serviço de Inspeção Federal SIF). Prior to slaughter, the animals were subjected to fasting for 14-16 h. After slaughter, the carcasses were identified, divided in half, weighed, washed and taken to a cold chamber for $24 \mathrm{~h}$ at a temperature varying between 0 and $2{ }^{\circ} \mathrm{C}$. The left half of the carcass was separated into primary cuts, where the forequarter was separated from the pistol cut and short ribs between the $5^{\text {th }}$ and $6^{\text {th }}$ rib bone, including neck, shoulder, arm, and five ribs. Through the rib cut at $22 \mathrm{~cm}$ of the vertebral column, the pistol cut was separated from the short ribs, which included the ribs from the sixth bones on, plus the abdominal muscles. Then, of the secondary commercial cuts, the forequarter and pistol cut portions of the 28 half-carcasses were set aside and weighed, then measured to determine the weight of the trimmed fat and the bone. The short ribs were divided into edible portions, bone, and fat trimming. For the primary and secondary commercial cuts, as well as the edible portion and the bone tissue of the primary cuts, weights were calculated in proportion to the cold half-carcasses, which, in turn, exhibited average weights of $104.3,109.8,116.1$, and 127.2 $\mathrm{kg}$, and slaughter weights of 434, 461, 476, and 522 $\mathrm{kg}$, respectively.

On the right half-carcasses, a cut was made between the $12^{\text {th }}$ and $13^{\text {th }}$ ribs, to expose the Longissimus dorsi muscle. After $30 \mathrm{~min}$ of exposure to air, to determine its coloration $(1=$ dark; $2=$ dark red; $3=$ slightly dark red; $4=$ red; and $5=$ bright red), texture $(1=$ very coarse; $2=$ coarse; $3=$ slightly coarse; $4=$ thin; $5=$ very thin), and marbling ( 1 to
$3=$ traces; 4 to $6=$ light; 7 to $9=$ small; 10 to $12=$ medium; 13 to $15=$ moderate; 16 to $18=$ abundant / abounding), according to the method described by Müller (1987). Next, the Longíssimus dorsi muscle, corresponding to the section between the $10^{\text {th }}$ and $12^{\text {th }}$ ribs, was removed, wrapped, and frozen in a commercial freezer $\left(-18^{\circ} \mathrm{C}\right)$ for $90 \mathrm{~d}$. After this period, a steak $2.5 \mathrm{~cm}$ in thickness was removed, from the cranial portion of the Longíssimus dorsi muscle, after $24 \mathrm{~h}$ of defrosting in a home refrigerator. Then, the steaks were roasted in an oven until they reached an internal temperature of $70^{\circ} \mathrm{C}$, and subjected to an evaluation of tenderness and palatability ( 1 = extremely tough, and tasteless; 2 = very tough, and lacking flavor; $3=$ tough, and a little tasty; 4 = slightly below average; $5=$ average; $6=$ slightly above average; $7=$ tender, and tasty; $8=$ very tender, and very tasty; and $9=$ extremely tender, and extremely tasty) carried out by a panel of five trained tasters (MÜLLER, 1987).

After the assumptions of normality and variance homogeneity were met, the data were submitted to variance analysis, polynomial regression, and Pearson correlation, 5\% was adopted as the significance level. The determination coefficient value was calculated from the sum of squares of a significant regression, divided by the sum of the total squares recalculated [sum of the regression squares + sum of error analysis squares of variance (pure error)]. The initial age was utilized as a covariable, and when non-significant, it was removed from the model.

The overall mathematical model used was $g_{\mathrm{ijk}}=$ $\mu+t_{i}+b_{j}+e_{i j k}$, where: $g_{i j k}=$ dependent variable; $\mu=$ overall mean; $t_{i}=$ effect of the treatment $i ; b_{j}=$ effect of the co-variable $\mathrm{j} ; \mathrm{e}_{\mathrm{ijk}}=$ residual experimental error. In the regression, the model used was: $\mathrm{g}_{\mathrm{ij}}$ $=\mathrm{b}_{0}+\mathrm{b}_{1} \mathrm{X}_{\mathrm{i}}+\mathrm{b}_{2} \mathrm{X}_{\mathrm{i}}^{2}+\mathrm{b}_{3} \mathrm{X}_{\mathrm{i}}^{3}+\mathrm{a}_{\mathrm{j}+} \varepsilon_{\mathrm{ij}}$, where: $\mathrm{g}_{\mathrm{ij}}=$ dependent variables; $\mathrm{b}$ 's $=$ regression coefficients; $\mathrm{X}_{\mathrm{i}}=$ independent variables; $\mathrm{a}_{\mathrm{j}}=$ deviations of regression; and $\varepsilon_{\mathrm{ij}}=$ residual random error. 


\section{Results and Discussion}

The consumption of dry matter, expressed as $\mathrm{kg}$ $\mathrm{d}^{-1}$ and $\%$ of body weight, varied in quadractly form $(\mathrm{P}<0.05)$ as a function of slaughter weight increase (Table 2), with the greatest values being observed for a slaughter weight of $461 \mathrm{~kg}$. These results differed from those reported in the literature, wherein it has often been reported that increasing slaughter weight does not influence dry matter intake (RESTLE et al., 1997; ARBOITTE et al., 2004a). Nonetheless, some authors (COSTA et al., 2002a) have verified that a reduction in dry matter intake ( $\%$ of the body weight) is correlated with increases in the slaughter weight of steers $(340,370,400$, and 430 $\mathrm{kg}$ ). According to NRC (1996), a reduction of feed intake with increase in body weight is associated with the action of leptin, because it indicates the presence of an increase in the deposition of body fat; this may explain the drop in the consumption of dry matter starting at body weights of $461 \mathrm{~kg}$. However the increase in dry matter intake from 434 to the $461 \mathrm{~kg}$ body weight, may be explained by the re-establishment of the size of the gastrointestinal tract, as evidenced by the evaluation of the weight of the components of the empty body of the animals (MISSIO et al., 2013b) demonstrating that previous to the finishing period was characterized by the existence of food restriction.

Table 2. Feed fractions intake, average daily gain and feed conversion of Purunã cows slaughter with different body weights.

\begin{tabular}{|c|c|c|c|c|c|c|c|c|c|}
\hline \multirow{2}{*}{ Items } & \multicolumn{4}{|c|}{ Slaughter weight $(\mathrm{kg})$} & \multirow{2}{*}{$\begin{array}{l}\mathrm{CV} \\
(\%)\end{array}$} & \multicolumn{3}{|c|}{$\mathrm{RE}-\mathrm{P}$ value } & \multirow{2}{*}{$\mathrm{R}^{2}$} \\
\hline & 434 & 461 & 496 & 522 & & $\mathrm{~L}$ & Q & $\mathrm{C}$ & \\
\hline \multicolumn{10}{|c|}{ Feed fractions intake } \\
\hline Dry matter, $\mathrm{kg} \mathrm{d}^{-1}$ & 10.74 & 12.30 & 11.43 & 11.11 & 16.00 & 0.882 & 0.036 & 0.311 & 0.57 \\
\hline Dry matter, \% BW & 2.63 & 2.96 & 2.66 & 2.47 & 9.80 & 0.095 & 0.009 & 0.084 & 0.31 \\
\hline Crude protein, $\mathrm{kg} \mathrm{d}^{-1}$ & 0.72 & 0.76 & 0.73 & 0.72 & 14.20 & 0.534 & 0.003 & 0.493 & 0.94 \\
\hline Crude protein, $\% \mathrm{BW}$ & 0.17 & 0.18 & 0.17 & 0.16 & 2.10 & 0.406 & $<0.000$ & 0.051 & 0.75 \\
\hline Neutral detergent neutral, $\mathrm{kg} \mathrm{d}^{-1}$ & 1.01 & 1.03 & 0.95 & 0.89 & 23.60 & 0.178 & 0.382 & 0.732 & -- \\
\hline Neutral detergent neutral, \% BW & 0.24 & 0.25 & 0.22 & 0.20 & 13.50 & 0.001 & 0.047 & 0.356 & 0.45 \\
\hline Total carbohydrates, $\mathrm{kg} \mathrm{d}^{-1}$ & 7.57 & 8.59 & 7.98 & 7.74 & 13.90 & 0.972 & 0.041 & 0.339 & 0.59 \\
\hline Total carbohydrates, \% BW & 1.86 & 2.07 & 1.85 & 1.72 & 6.00 & 0.060 & 0.011 & 0.084 & 0.31 \\
\hline Non-fibrous carbohydrates, $\mathrm{kg} \mathrm{d}^{-1}$ & 4.15 & 4.62 & 4.32 & 4.21 & 14.00 & 0.863 & 0.029 & 0.371 & 0.71 \\
\hline Non-fibrous carbohydrates, \% BW & 1.01 & 1.11 & 1.00 & 0.94 & 4.60 & 0.013 & 0.004 & 0.050 & 0.40 \\
\hline Total digestible nutrients, $\mathrm{kg} \mathrm{d}^{-1}$ & 6.39 & 7.20 & 6.72 & 6.56 & 13.40 & 0.969 & 0.028 & 0.332 & 0.66 \\
\hline Total digestible nutrients, $\%$ BW & 1.57 & 1.74 & 1.56 & 1.46 & 4.90 & 0.036 & 0.005 & 0.051 & 0.34 \\
\hline Average daily gain (ADG), $\mathrm{kg} \mathrm{d}^{-1}$ & 1.74 & 1.50 & 1.46 & 1.36 & 19.36 & 0.015 & 0.316 & 0.350 & 0.40 \\
\hline $\mathrm{FC}, \mathrm{kg} \mathrm{DM} \mathrm{kg}^{-1}$ of ADG & 6.17 & 8.20 & 7.83 & 8.17 & 17.56 & 0.051 & 0.056 & 0.023 & 0.40 \\
\hline
\end{tabular}

Dry matter $\left(\mathrm{DM}, \mathrm{kg} \mathrm{d}^{-1}\right)=-12.2048+0.52 \mathrm{x}-0.00055 \mathrm{x}^{2}+0.026 \mathrm{IW}$; DM $(\% \mathrm{BW})=-2.9652+0.14 \mathrm{x}-0.00015 \mathrm{x}^{2}-0.00062 \mathrm{IW}$; crude protein $\left(\mathrm{CP}, \mathrm{kg} \mathrm{d}^{-1}\right)=-0.4025+0.0171 \mathrm{x}-0.0000181 \mathrm{x}^{2}+0.0019 \mathrm{IW} ; \mathrm{CP}(\% \mathrm{BW})=-1.011+0.0052 \mathrm{x}-0.0000057 \mathrm{x}^{2}+$ $0.000024 \mathrm{IW}$; neutral detergent fiber $(\mathrm{NDF}, \% \mathrm{BW})=-1.215+0.0063 \mathrm{x}-0.0000073 \mathrm{x}^{2}+0.00021 \mathrm{PI}$; total carbohydrates $(\mathrm{TC}, \mathrm{kg}$ $\left.\mathrm{d}^{-1}\right)=-8.137+0.347 \mathrm{x}-0.00036 \mathrm{x}^{2}+0.0192 \mathrm{PI}$; TC $(\% \mathrm{BW})=-1.961+0.093 \mathrm{x}-0.0001 \mathrm{x}^{2}-0.00028 \mathrm{IW}$; non-fibrous carbohydrates $\left(\mathrm{NFC}, \mathrm{kg} \mathrm{d}^{-1}\right)=-3.6967+0.1575 \mathrm{x}-0.00017 \mathrm{x}^{2}+0.0108 \mathrm{PI}$; NFC $(\% \mathrm{BW})=-0.9088+0.044 \mathrm{x}-0.000047 \mathrm{x}^{2}-0.0000317 \mathrm{IW} ;$ total digestible nutrients $\left(\mathrm{TDN}, \mathrm{kg} \mathrm{d}^{-1}\right)=-6.3583+0.271 \mathrm{x}-0.00028 \mathrm{x}^{2}+0.016 \mathrm{IW}$; TDN $(\% \mathrm{BW})=-1.5536+0.074 \mathrm{x}-0.00008 \mathrm{x}^{2}-$ $0.0002 \mathrm{BW}$; average daily gain $(\mathrm{ADG})=2.115-0.00374 \mathrm{x}+0.00304 \mathrm{IW}$; feed conversion $(\mathrm{FC})=-3464.3+21.71 \mathrm{x}-0.045 \mathrm{x}^{2}+$ $0.000031 \mathrm{x}^{3} ; \mathrm{x}=$ slaughter weight; $\mathrm{BW}=$ body weight; IW = initial body weight; $\mathrm{RE}=$ regression equations. 
The consumption of the remaining nutrients (Table 2), with the exception of neutral detergent fiber ( $\%$ body weight) exhibited variation similar to that of dry matter intake. However, the consumption of neutral detergent fiber $\left(\mathrm{kg} \cdot \mathrm{d}^{-1}\right)$, was not affected $(\mathrm{P}>0.05)$ by the increase in slaughter weight. It is noteworthy that the factors driving this lack of variance in fiber consumption $\left(\mathrm{kg} \cdot \mathrm{d}^{-1}\right)$ were not detected in this study, except for the fact that this variable exhibited the highest coefficient of variation compared to other variables associated with nutrient consumption. However, in general, it is appropriate to state that the outcomes of this study were consistent with the conclusions of previously published studies, as it has been verified that in studies that evaluated bovine slaughter weights, nutrient consumption was reflected in the variation of dry matter consumption (COSTA et al., 2002a; ARBOITTE et al., 2004a).

The average daily gain decreased linearly $(\mathrm{P}<0.05)$ by increased slaughter weight (Table 2 ), in which the drop in animal performance, in relation to weight $434 \mathrm{~kg}$ was of 13,16 , and $21 \%$ for the slaughter weights of 461, 476, and $522 \mathrm{~kg}$, respectively. These phenomena are associated with increased requirement of energy for maintenance with increased body weight; this ultimately leads to the animal having less energy available for weight gain (NRC, 1996). In addition, the increase in the length of the confinement period led to more energyrich weight gain, as a larger portion of the total body mass was composed of adipose tissue deposits (MISSIO et al., 2013a). The deposition of adipose tissue requires more energy than other tissues, resulting in a drop in weight gain that is aggravated by the decrease in the total digestible nutrient intake, which occurred at the highest weights (Table 2). In this case, an alternative method of facilitating the larger weight gains desired during the finishing period would be to increase of energy content of the diets with increase of confinement period, as demonstrated by Restle et al. (2001a).
The values pertaining to average daily gain (1.52 $\mathrm{kg} \cdot \mathrm{d}^{-1}$ ) were generally lower than those reported by Moura et al. (2013), in which weight gains of 1.81 and $2.00 \mathrm{~kg} \cdot \mathrm{d}^{-1}$ in interbred Purunã cows were yielded, with an initial body weight of $437.7 \mathrm{~kg}$ and an average age of 7.2 years when the confinement period was completed. In contrast, the average daily gain observed was nearly average $(1.65 \mathrm{~kg} \cdot \mathrm{d}$ $\left.{ }^{1}\right)$ as reported by Restle et al. (2001a), in a study of Charolais cows with initial weight of $378.8 \mathrm{~kg}$ and an average age of 7 years old, that were fed in confinement, on a diet either with or without sodic monensin, that contained $65 \%$ corn silage. However, the average daily gain observed in this study was higher than the average value $\left(1.38 \mathrm{~kg} \cdot \mathrm{d}^{-1}\right)$ reported by Kuss et al. (2008) in a study assessing the effects of confinement diets containing 58\% corn silage and different quantities of sodic monensin in Charolais/ Nellore crossbreed cows. Restle et al. (2001b), when evaluating the genetics of cull cows fed in confinement on diets containing $65 \%$ sorghum silage, reported the average daily gain of Charolais (C), Nellore (N), 1/2 CN, and 1/2 NC cows to be $1.55,1.29,1.62$, and $1.42 \mathrm{~kg} \cdot \mathrm{d}^{-1}$, respectively, which, when compared to the outcomes obtained, points toward the potential for weight gain in cows of the Purunã breed.

The elevated weight gains seen in the experimental animals, especially in cows at 434 $\mathrm{kg}$, are mainly due to compensatory gain, which, according to Fontes et al. (2007), is more intense over the first $28 \mathrm{~d}$ of re-feeding. These compensatory gains manifest in animals that have experienced feed restriction severe enough to affect their growth; after being provided with adequate nutrition, the animal's exhibit above-average weight gains. The intensity of this phenomenon is determined by the animal's age at the start of the restriction period, the severity and duration of the nutritional stress, and the nature of the food restriction (ALVES, 2003). Despite this, the compensatory weight gain event is commonly observed in growing bovines that have been finished in confinement, and which had previously kept in 
low-quality or low-availability pastures (BAIL et al., 2000; FONTES et al., 2007). However, these compensatory gain events are also observed in cows finished in confinement (RESTLE et al., 2001a) or in pastures of reasonable quality (RESTLE et al., 1998), because prior to finishing these animals are, generally grazed in low-availability and/or lowquality pastures, as in this study.

The feed conversion showed better adjustment $(\mathrm{P}<0.05)$ to the cubic regression, wherein the worst slaughter weights were found to be 461 and $522 \mathrm{~kg}$ (Table 2). Although this variable reduced by $4.7 \%$ when slaughter weight was increased from 461 to $476 \mathrm{~kg}$, the lowest value was observed for the slaughter weight of $434 \mathrm{~kg}$. On average, the best feed conversion was observed for the two lowest slaughter body weights relative to two greatest (7.2 vs. $8.0 \mathrm{~kg}$ of dry matter $\mathrm{kg}^{-1}$ of weight gain). These results were similar to those reported by Costa et al. (2002a) and Arboitte et al. (2004a), who found that feed conversion increased with slaughter weight increase, which was attributed to the increase in maintenance energy demands with increase in body weight, and because of average daily gain be more energetic with the advance of slaughter weight. In contrast, these outcomes differ from those obtained by Restle et al. (1997), who found that feed conversion in Charolais steers was not affected by slaughter weight increases; this was attributed to the fact that heavy cattle are characterized by increased growth and fewer fatty deposits. The researchers ascribed this to the fact that fat deposition is delayed in the Charolais breed. The variation in feed conversion detected in this study is attributable to variation in the consumption of dry matter $(r=0.30 ; P=0.049)$ and daily weight gains $(\mathrm{r}=-0.67 ; \mathrm{P}<0.0001)$. The values found for feed conversion (average of $7.59 \mathrm{~kg}$ of dry matter $\mathrm{kg}^{-1}$ of weight gain) were lower than those (average of 8.98 $\mathrm{kg}$ of dry matter $\mathrm{kg}^{-1}$ of weight gain) reported by Restle et al. (2001b) in relation to cows of different genetic groups (C, N, 1/2 CN and $1 / 2 \mathrm{NC}$ ). This demonstrates that food transformation into meat is highly biologically efficient in cull cows of the Purunã breed.

The increase in slaughter body weight resulted in a rise $(\mathrm{P}<0.05)$ in the absolute weight of the pistol cut, forequarter and short ribs (Table 3 ). These results are similar to those of previous studies, which have overall reported an increase in the absolute weights of commercial cuts due to increases in slaughter body weight (COSTA et al., 2002b; ARBOITTE et al., 2004b; KUSS et al., 2005). When the weights of commercial cuts were expressed in relation to cold carcass weight, only the short ribs weight was affected $(\mathrm{P}<0.05)$ by increased slaughter weight, which increased linearly. The larger proportion of short ribs seems to favor the South Brazil industry, since much of this region, as well as in Rio Grande do Sul, the short ribs have remuneration similar to the pistol cut, determining better economic return in the marketing of carcasses with this feature (VAZ et al., 2012).

The commercial cut proportions obtained differed from those reported in the literature, wherein it has been demonstrated that, in growing animals, the increase of slaughter weight does not affect the forequarter proportion, but reduces the pistol cut proportion by increasing the proportion of the weight of the short ribs because of the elevated levels of fatty deposits found near the rib region with the animals finishing (COSTA et al., 2002b; ARBOITTE et al., 2004b). However, according to Berg and Butterfield (1976), an animal tends to maintain, within certain limits, a balance between the forequarters and the hindquarter. On the other hand, the results observed were similar to those obtained by Kuss et al. (2005), who verified that the short ribs proportion increased and forequarter proportion decreased, whereas the pistol cut proportion was not affected by increases in the slaughter weight of cull cows. These differences in results between studies may be associated with the larger range of weights evaluated by these researchers (from 465 to 566 $\mathrm{kg}$ ), because the animals were close to their adult weight, when the rates of body tissue deposition 
reduce (LAWRENCE; FOWLER, 2005). This is made evident by the occurrence of a decrease in the forequarter proportion with increased slaughter weight in a study by Kuss et al. (2005). This demonstrates that the forequarter exhibits a growth rate higher that of the carcass. However, in this study, the maintenance of the forequarter proportion with increased slaughter weight indicates that this cut grows at a rate similar to that of the carcass as a whole.

Table 3. Weight forequarter, short ribs and pistol cut of left half-carcass of Purunã cows slaughter with different body weights.

\begin{tabular}{|c|c|c|c|c|c|c|c|c|c|}
\hline \multirow{2}{*}{ Items } & \multicolumn{4}{|c|}{ Slaughter weight $(\mathrm{kg})$} & \multirow{2}{*}{$\begin{array}{l}\text { CV } \\
(\%)\end{array}$} & \multicolumn{3}{|c|}{$R E-P$ value } & \multirow{2}{*}{$\mathrm{R}^{2}$} \\
\hline & 434 & 461 & 476 & 522 & & $\mathrm{~L}$ & Q & $\mathrm{C}$ & \\
\hline Forequarter, kg & 55.04 & 58.76 & 62.09 & 65.81 & 14.11 & 0.005 & 0.747 & 0.825 & 0.22 \\
\hline Forequarter, $\% \mathrm{CCW}$ & 52.60 & 53.37 & 53.41 & 51.72 & 3.25 & 0.321 & 0.144 & 0.989 & -- \\
\hline Short ribs, $\mathrm{kg}$ & 18.63 & 20.44 & 21.06 & 25.38 & 16.33 & 0.006 & 0.726 & 0.855 & 0.38 \\
\hline Short ribs, $\% \mathrm{CCW}$ & 17.89 & 18.53 & 18.05 & 19.89 & 7.73 & 0.041 & 0.496 & 0.434 & 0.24 \\
\hline Pistol cut, kg & 49.25 & 51.06 & 54.04 & 61.41 & 10.85 & 0.003 & 0.619 & 0.779 & 0.44 \\
\hline Pistol cut, $\% \mathrm{CCW}$ & 47.40 & 46.63 & 46.59 & 48.28 & 3.63 & 0.321 & 0.144 & 0.989 & -- \\
\hline
\end{tabular}

Forequarter $(\mathrm{kg})=2.472+0.1224 \mathrm{x}$; short ribs $(\mathrm{kg})=-15.03+0.077 \mathrm{x} ;$ short ribs $(\%)=8.112+0.022 \mathrm{x} ;$ pistol cut $(\mathrm{kg})=-13.83+$ $0.0143 \mathrm{x} ; \mathrm{CCW}=$ cold carcass weight; $\mathrm{RE}=$ regression equation.

The edible portion $(\mathrm{kg})$, made up of muscle and fat, increased linearly $(\mathrm{P}<0.05)$ in the short ribs and pistol cut, but did not change in the forequarter when slaughter weight was increased (Table 4). Expressed relative to cold carcass weight, this variable changed only for the short ribs, where it increased linearly. Despite this change, the increase in the edible portion of the carcass as a whole was previously demonstrated by Missio et al. (2013a), who evaluated the carcass characteristics of the animals in this study. The increase in the edible portion of the short ribs occurred because the size of this particular cut increases with overall weight, as fatty deposits increase (VAZ et al., 2012). In this study, it was possible to determine that the weight of the edible portion was correlated $(\mathrm{P}=0.52 ; \mathrm{P}=$ 0.019 ) with fat trimming, but only for the short ribs. This, in turn, shows that the fatty deposits had a greater impact on this region as finishing progressed. These outcomes generally reflect the order of body tissues deposition, in which the bone tissue grows most when the animal is youngest, the muscles grow most during an intermediate developmental stage, and adipose grows quickly during more advanced developmental stages (BERG; BUTTERFIELD, 1976).

The weight of bone tissue increased linearly ( $\mathrm{P}$ $<0.05$ ) in the pistol cut, but it did not change in forequarter and short ribs with increased slaughter weight (Table 4). These results reveal a loss of bone density due to the inadequate nutritional conditions that characterize the period prior to finishing; however, this loss of density was recovered during the re-feeding period. These results are consistent with the results of Lawrence and Fowler (2005), who found that animals experiencing compensatory weight gains may experience growth in bone size, if not in density; this occurs mainly in bones that define the width, length, and body perimeter. However, this effect may only occur in the pistol cut, and may be associated with the fact that this commercial cut contains the largest proportion of carcass bone, representing on average $7.5,2.9$, and $15.6 \%$ of the cold carcass weight of the forequarter, short ribs, and pistol cut, respectively. Expressed in terms of cold carcass weight, the bone tissue at the pistol cut and short ribs was not affected, although it decreased linearly in the forequarter with increased 
slaughter weight. Such outcomes were associated with variance in the masses of body tissues: because the sum of these tissue mass proportions is always equal to $100 \%$ in each commercial cut, increases in one tissue result in reductions in others. The greater correlation between the forequarter and edible portion of this cut $(\mathrm{r}=0.88 ; \mathrm{P}<0.0001)$, in relation to correlation between the forequarter weight and bone tissue $(\mathrm{r}=0.60 ; \mathrm{P}=0.004)$, shows that the increase in the absolute weight of the forequarter occurred because the deposition of tissues that compose the edible portion of the cut (muscle and fat) increased at the expense of bone deposition, which was negatively correlated $(\mathrm{r}=-0.39 ; \mathrm{P}=$ 0.049 ) with the edible portion of the forequarter.

Table 4. Weights of edible portion, bones and fat trimmings of commercials cut of Purunã cows slaughter with different body weights.

\begin{tabular}{|c|c|c|c|c|c|c|c|c|c|}
\hline \multirow{2}{*}{ Items } & \multicolumn{4}{|c|}{ Slaughter weight $(\mathrm{kg})$} & \multirow{2}{*}{$\begin{array}{l}\mathrm{CV} \\
(\%) \\
\end{array}$} & \multicolumn{3}{|c|}{$R E-P$ value } & \multirow{2}{*}{$\mathrm{R}^{2}$} \\
\hline & 434 & 461 & 476 & 522 & & $\mathrm{~L}$ & Q & $\mathrm{C}$ & \\
\hline \multicolumn{10}{|c|}{ Forequarter } \\
\hline Edible portion, $\mathrm{kg}$ & 25.80 & 26.24 & 29.17 & 28.28 & 17.18 & 0.366 & 0.598 & 0.464 & -- \\
\hline Edible portion, $\% \mathrm{CCW}$ & 24.50 & 23.83 & 25.14 & 22.26 & 9.05 & 0.127 & 0.311 & 0.280 & -- \\
\hline Bones, kg & 8.06 & 9.11 & 8.42 & 8.24 & 12.33 & 0.912 & 0.243 & 0.225 & -- \\
\hline Bones, \% CCW & 7.74 & 8.39 & 7.27 & 6.49 & 10.94 & 0.008 & 0.190 & 0.050 & 0.35 \\
\hline Fat trimmings, $\mathrm{kg}$ & 2.87 & 3.96 & 4.18 & 4.31 & 22.08 & 0.022 & 0.101 & 0.87 & 0.29 \\
\hline Fat trimmings, $\% \mathrm{CCW}$ & 2.80 & 3.66 & 3.64 & 3.42 & 13.81 & 0.382 & 0.134 & 0.692 & -- \\
\hline \multicolumn{10}{|c|}{ Short ribs } \\
\hline Edible portion, $\mathrm{kg}$ & 15.39 & 17.30 & 17.28 & 22.10 & 17.78 & 0.002 & 0.564 & 0.621 & 0.44 \\
\hline Edible portion, $\% \mathrm{CCW}$ & 14.73 & 15.64 & 14.88 & 17.31 & 8.78 & 0.009 & 0.559 & 0.226 & 0.35 \\
\hline Bones, $\mathrm{kg}$ & 3.25 & 3.14 & 3.78 & 3.28 & 28.77 & 0.871 & 0.563 & 0.347 & -- \\
\hline Bones, \% CCW & 3.15 & 2.89 & 3.17 & 2.58 & 12.61 & 0.182 & 0.636 & 0.402 & -- \\
\hline Fat trimmings, $\mathrm{kg}$ & 0.98 & 1.38 & 1.41 & 1.66 & 22.14 & 0.002 & 0.310 & 0.577 & 0.44 \\
\hline Fat trimmings, $\% \mathrm{CCW}$ & 0.95 & 1.27 & 1.22 & 1.33 & 14.97 & 0.099 & 0.296 & 0.494 & -- \\
\hline \multicolumn{10}{|c|}{ Pistol cut } \\
\hline Edible portion, $\mathrm{kg}$ & 33.03 & 34.25 & 36.23 & 41.20 & 11.46 & 0.004 & 0.632 & 0.794 & 0.40 \\
\hline Edible portion, $\% \mathrm{CCW}$ & 31.81 & 31.25 & 31.18 & 32.39 & 4.13 & 0.384 & 0.170 & 0.961 & -- \\
\hline Bones, kg & 16.22 & 16.82 & 17.81 & 20.21 & 11.10 & 0.003 & 0.637 & 0.776 & 0.41 \\
\hline Bones, \% CCW & 15.59 & 15.38 & 15.40 & 15.89 & 6.48 & 0.568 & 0.494 & 0.974 & -- \\
\hline Fat trimmings, $\mathrm{kg}$ & 2.58 & 3.47 & 3.66 & 4.03 & 22.48 & 0.011 & 0.257 & 0.808 & 0.34 \\
\hline Fat trimmings, $\% \mathrm{CCW}$ & 2.54 & 3.23 & 3.20 & 3.20 & 12.54 & 0.290 & 0.302 & 0.711 & -- \\
\hline
\end{tabular}

Forequarter bones $(\%)=15.63-0,0172 \mathrm{x}$; fat trimmings of forequarter $(\mathrm{kg})=-3.169+0.0148 \mathrm{x}$; edible portion of short ribs $(\mathrm{kg})=$ $-17.874+0.0758 \mathrm{x}$; edible portion of short ribs $(\%)=2.218+0.0283 \mathrm{x}$; fat trimmings of short ribs $(\mathrm{kg})=-2.078+0.0072 \mathrm{x}$; edible portion of pistol cut $(\mathrm{kg})=-9.3534+0.0962$; bones of pistol cut $(\mathrm{kg})=-4.46+0.047 \mathrm{x}$; fat trimmings pistol cut $(\mathrm{kg})=-3.81+$ $0.015 \mathrm{x} ; \mathrm{CCW}=$ cold carcass weight; $\mathrm{RE}=$ regression equation .

Increasing the slaughter weight caused a linear increase $(\mathrm{P}<0.05)$ in fat trimmings $(\mathrm{kg})$ in all primary commercial cuts; however, when expressed in relation to the cold carcass weight, the proportion of fat trimmings in primary commercial cuts was not affected (Table 4). This increase in fat is detrimental to the producer, as this excess fat both lacks economic value, and leads to increases in production costs because of the larger quantity of food required for its deposition. Vaz et al. (2012) stated that a lack of excess fat that is not useful for the market is essential for sustainability of animal production, particularly for cull cows, which according to Cattelam et al. (2010); generate more fat trimming 
relative to steer slaughter weight. However, despite the demands on the carcass finishing and animal slaughter weight, they have changed over time depending on market requirements. Now part of Brazilian slaughterhouses seek the slaughter of animals with high body weights $(\geq 480 \mathrm{~kg}$ ) and/or that have higher degrees of carcass finishing $(\geq 3$ $\mathrm{mm}$ ) in order to reduce operational cost and weight loss of carcasses during cooling.

Increases in slaughter weight did not affect the weights of forequarter meat cuts (Table 5), with the exception of chuck weight ( $\mathrm{kg}$ and $\%$ of the carcass weight), which increased linearly. This increase in chuck weight accounts for the increase in the absolute forequarter weight $(\mathrm{r}=0.74 ; \mathrm{P}=0.0002)$ seen when slaughter weights are increased, which was also correlated with oyster blade $(\mathrm{r}=0.56$; $\mathrm{P}$ $=0.009)$, shoulder muscles $(\mathrm{r}=0.52 ; \mathrm{P}=0.017)$, and breast muscles increases $(\mathrm{r}=0.77 ; \mathrm{P}<0.001)$. These changes in chuck weight were similar to those reported by Jorge et al. (1997), who observed an increase in the weight of entire chucks due to increases in steers slaughter weights $(405,460$, and $530 \mathrm{~kg}$ ); this phenomenon that was attributed to the higher growth maintenance of the muscles of the spinal column with advancing of age.

Table 5. Meat cuts of the forequarter of left half-carcass of Purunã cows slaughtered with different body weights.

\begin{tabular}{|c|c|c|c|c|c|c|c|c|c|}
\hline \multirow{2}{*}{ Items } & \multicolumn{4}{|c|}{ Slaughter weight (kg) } & \multirow{2}{*}{$\begin{array}{l}\text { CV } \\
(\%)\end{array}$} & \multicolumn{3}{|c|}{$\mathrm{RE}-\mathrm{P}$ value } & \multirow{2}{*}{$\mathrm{R}^{2}$} \\
\hline & 434 & 461 & 476 & 522 & & $\mathrm{~L}$ & $\mathrm{Q}$ & $\mathrm{C}$ & \\
\hline Blade clod, kg & 2.55 & 2.98 & 3.44 & 3.93 & 39.38 & 0.077 & 0.800 & 0.799 & -- \\
\hline Blade clod, \% CCW & 2.47 & 2.60 & 2.95 & 3.07 & 33.47 & 0.264 & 0.830 & 0.711 & -- \\
\hline Chuck tender, $\mathrm{kg}$ & 1.36 & 1.27 & 1.38 & 1.40 & 20.84 & 0.682 & 0.739 & 0.536 & -- \\
\hline Chuck tender, \% CCW & 1.32 & 1.16 & 1.19 & 1.10 & 19.63 & 0.174 & 0.621 & 0.589 & -- \\
\hline Shouder clod, kg & 5.58 & 6.47 & 6.16 & 6.41 & 22.59 & 0.429 & 0.559 & 0.575 & -- \\
\hline Shouder clod, \% CCW & 5.38 & 6.11 & 5.34 & 5.06 & 25.46 & 0.529 & 0.534 & 0.396 & -- \\
\hline Fore shank, $\mathrm{kg}$ & 6.28 & 3.96 & 5.14 & 5.62 & 40.18 & 0.914 & 0.182 & 0.279 & -- \\
\hline Fore shank, \% CCW & 5.74 & 3.59 & 4.42 & 4.44 & 29.48 & 0.344 & 0.093 & 0.171 & -- \\
\hline Neck muscles, $\mathrm{kg}$ & 6.11 & 7.50 & 8.18 & 5.64 & 42.62 & 0.687 & 0.142 & 0.809 & -- \\
\hline Neck muscles, \% CCW & 5.91 & 6.69 & 7.09 & 4.45 & 35.52 & 0.233 & 0.107 & 0.776 & -- \\
\hline Chuck, kg & 3.03 & 4.07 & 4.96 & 5.58 & 28.37 & 0.003 & 0.357 & 0.651 & 0.30 \\
\hline Chuck, \% PCF & 2.93 & 3.63 & 4.24 & 4.36 & 22.34 & 0.015 & 0.226 & 0.604 & 0.41 \\
\hline Breast muscle, $\mathrm{kg}$ & 3.44 & 2.96 & 3.34 & 3.63 & 29.47 & 0.592 & 0.469 & 0.544 & -- \\
\hline Breast muscle, \% CCW & 3.22 & 2.65 & 2.86 & 2.85 & 20.16 & 0.477 & 0.287 & 0.408 & -- \\
\hline
\end{tabular}

Chuck $(\mathrm{kg})=-3.452+0.0154 \mathrm{x} ;$ chuck $(\%)=-8.67116+0.02778 \mathrm{x} ; \mathrm{x}=$ slaughter weight; $\mathrm{CCW}=$ cold carcass weight; RE $=$ regression equation.

Of the pistol cuts (Table 6), the weights $(\mathrm{kg})$ of the rump cap, knuckle, topside, tail of round and striploin increased linearly $(\mathrm{P}<0.05)$ with slaughter weight. However, when these weights were expressed in relation to the weight of the cold carcass, only the striploin was affected by the slaughter weight increase, and it increased linearly. The remaining meat cuts of the pistol cut, with the exception of the tenderloin cut, were not affected by the slaughter weights. The tenderloin weight (kg and
$\%$ of the cold carcass weight) varied quadratically as slaughter weight increased, with the greatest values observed at a slaughter weight of $476 \mathrm{~kg}$. The linear variation of the weight of striploin and the quadratic variation of tenderloin weight revealed that striploin, represented mainly by the Longíssimus dorsi muscle, maintained a higher rate of growth as slaughter weight increased than tenderloin, which is represented by the Psoas maior muscle. This may be related to fat deposition which does not occur 
in the tenderloin. This means that both the order of body tissue deposition, particularly that of adipose tissues, as well as fat distribution in the carcass determines the variation of meat cuts prepared for commercial markets. In addition, although the animals used were adults, they experienced a period of body tissue re-establishment due to the period of food restriction inflicted prior to the finishing stage.
Thus, the variations in the weights of meat cuts may also be reflected in the growth patterns of the body, which progress from the extremities towards the axial skeleton and loin. Bone recovery may be another relevant aspect, as the longitudinal growth of muscles is highly positively correlated with annex bone growth (LAWRENCE; FOWLER, 2005).

Table 6. Meat cuts of the pistol cut of left half-carcass of Purunã cows slaughtered with different body weights.

\begin{tabular}{|c|c|c|c|c|c|c|c|c|c|}
\hline \multirow{2}{*}{ Items } & \multicolumn{4}{|c|}{ Slaughter weight $(\mathrm{kg})$} & \multirow{2}{*}{$\begin{array}{l}\mathrm{CV} \\
(\%)\end{array}$} & \multicolumn{3}{|c|}{$\mathrm{RE}-\mathrm{P}$ value } & \multirow{2}{*}{$\mathrm{R}^{2}$} \\
\hline & 434 & 461 & 476 & 522 & & $\mathrm{~L}$ & Q & $\mathrm{C}$ & \\
\hline Tenderloin, kg & 1.80 & 2.02 & 2.44 & 2.18 & 16.59 & 0.096 & 0.039 & 0.156 & 0.40 \\
\hline Tenderloin, \% CCW & 1.73 & 1.84 & 2.10 & 1.71 & 9.63 & 0.946 & 0.007 & 0.067 & 0.40 \\
\hline Rump cap, kg & 1.43 & 1.45 & 1.99 & 2.03 & 19.26 & 0.008 & 0.394 & 0.115 & 0.38 \\
\hline Rump cap, \% CCW & 1.37 & 1.32 & 1.71 & 1.60 & 13.43 & 0.099 & 0.304 & 0.117 & -- \\
\hline Knuckle, kg & 5.19 & 5.89 & 5.96 & 6.69 & 16.74 & 0.039 & 0.647 & 0.481 & 0.26 \\
\hline Knuckle, \% CCW & 4.98 & 5.36 & 5.13 & 5.26 & 11.81 & 0.554 & 0.522 & 0.298 & -- \\
\hline Eyeround, kg & 2.06 & 2.16 & 2.50 & 2.52 & 17.67 & 0.083 & 0.436 & 0.573 & -- \\
\hline Eyeround, \% CCW & 1.98 & 1.97 & 2.15 & 1.98 & 8.18 & 0.800 & 0.121 & 0.245 & -- \\
\hline Topside, $\mathrm{kg}$ & 7.10 & 7.63 & 7.50 & 9.18 & 19.31 & 0.044 & 0.580 & 0.608 & 0.25 \\
\hline Topside, \% CCW & 6.81 & 6.95 & 6.46 & 7.22 & 16.28 & 0.595 & 0.448 & 0.539 & -- \\
\hline Flat, $\mathrm{kg}$ & 4.71 & 4.27 & 4.42 & 5.18 & 19.88 & 0.318 & 0.204 & 0.751 & -- \\
\hline Flat, \% CCW & 4.52 & 3.89 & 3.81 & 4.07 & 20.90 & 0.456 & 0.134 & 0.698 & -- \\
\hline Tail of rump, $\mathrm{kg}$ & 0.75 & 1.04 & 1.26 & 1.27 & 24.92 & 0.008 & 0.087 & 0.555 & 0.38 \\
\hline Tail of rump, $\% \mathrm{CCW}$ & 0.72 & 0.95 & 1.09 & 1.00 & 26.84 & 0.132 & 0.079 & 0.831 & -- \\
\hline Heel, kg & 5.41 & 4.93 & 4.67 & 6.12 & 20.11 & 0.267 & 0.083 & 0.514 & -- \\
\hline Heel, \% CCW & 5.19 & 4.49 & 4.02 & 4.81 & 16.54 & 0.478 & 0.332 & 0.469 & -- \\
\hline Rump, kg & 4.56 & 5.05 & 5.51 & 6.03 & 17.96 & 0.018 & 0.850 & 0.507 & 0.32 \\
\hline Rump, \% CCW & 4.37 & 4.60 & 4.75 & 4.74 & 15.57 & 0.287 & 0.870 & 0.338 & -- \\
\hline Striploin, $\mathrm{kg}$ & 6.38 & 5.50 & 7.31 & 9.33 & 17.18 & 0.001 & 0.366 & 0.727 & 0.50 \\
\hline Striploin, \% CCW & 6.12 & 5.01 & 6.30 & 7.33 & 10.91 & 0.008 & 0.198 & 0.582 & 0.38 \\
\hline
\end{tabular}

Tenderloin $(\mathrm{kg})=-41.367+0.178 \mathrm{x}-0.00018 \mathrm{x}^{2}$; tenderloin $(\%)=-32.93+0.146 \mathrm{x}-0.00015 \mathrm{x}^{2} ;$ rump cover $(\mathrm{kg})=-1.625+$ $0.007 x$; Knuckle $(\mathrm{kg})=-1.45+0.016$; topside $(\mathrm{kg})=-3.15+0.023 \mathrm{x}$; tail of rump $(\mathrm{kg})=-1.63+0.0057 \mathrm{x} ;$ rump $(\mathrm{kg})=-2.97+$ $0.017 \mathrm{x}$; striploin $(\mathrm{kg})=-9.185+0.035 ;$ striploin $(\%)=-0.786+0.015 \mathrm{x} ; \mathrm{x}=$ slaughter weight; $\mathrm{ER}=$ regression equation.

Meat color increased linearly $(\mathrm{P}<0.05)$ as a function of slaughter weight (Table 7), varying between "slightly dark red" and "red". These results differ from those produced by Restle et al. (1996), Costa et al. (2002c), and Arboitte et al. (2004c); these previous studies did not observe any change in the color of steers meat due to increases in slaughter weight. According to Boggs and Merkel (1981), meat color darkens because of increase in myoglobin concentration, coupled with increase in animal's age. Nevertheless, Cranwell et al. (1996) studied the effect of re-feeding cull cows in confinement on meat color and verified that $56 \mathrm{~d}$ feeding periods combined with high-calorie diets was sufficient to promote a reduction myoglobin concentration, resulting in brighter meats; this may explain the 
outcomes of this study. It is worth nothing that meat coloration is an important economic factor, because darker meats are considered less appealing by consumers (MÜLLER, 1987).

Table 7. Meat characteristics of Purunã cows slaughtered with different body weights.

\begin{tabular}{|c|c|c|c|c|c|c|c|c|c|}
\hline \multirow{2}{*}{ Items } & \multicolumn{4}{|c|}{ Slaughter weight (kg) } & \multirow{2}{*}{$\mathrm{CV}$} & \multicolumn{3}{|c|}{$\mathrm{RE}$ - $\mathrm{P}$ value } & \multirow{2}{*}{$\mathrm{R}^{2}$} \\
\hline & 434 & 461 & 476 & 522 & & $\mathrm{~L}$ & $\mathrm{Q}$ & $\mathrm{C}$ & \\
\hline Color, points & 3.55 & 3.45 & 3.52 & 4.07 & 15.16 & 0.038 & 0.186 & 0.091 & 0.20 \\
\hline Texture, points & 3.78 & 3.17 & 3.33 & 3.49 & 14.11 & 0.325 & 0.626 & 0.132 & -- \\
\hline Marbling, points & 2.44 & 5.33 & 7.22 & 9.00 & 33.51 & $<0.001$ & 0.919 & 0.317 & 0.53 \\
\hline Tenderness, points & 5.75 & 6.20 & 5.92 & 6.32 & 11.11 & 0.215 & 0.264 & 0.942 & -- \\
\hline Palatability, points & 4.83 & 5.50 & 5.71 & 6.19 & 11.98 & 0.029 & 0.599 & 0.943 & 0.24 \\
\hline
\end{tabular}

Color $=1.474+0.0045 \mathrm{x}$; marbling $=-37.6958+0.09313 \mathrm{x}$; palatability $=2.258+0.0071 \mathrm{x} ; \mathrm{x}=$ slaughter weight; $\mathrm{RE}=$ regression equation.

The increase in slaughter weight did not affect ( $\mathrm{P}$ $>0.05$ ) meat textures (Table 7), which was classified as "slightly coarse" (average, 3.44 points). These results are similar to those obtained by Kuss et al. (2005), who did not detect any changes in meat texture due to increased slaughter weight $(465,507$, and $566 \mathrm{~kg}$ ) during their comparison of the physical composition of the carcass and the meat quality of purebred or crossbred Charolais and Nellore cull cows, in their first or second generation of crossbreeding, during which the meat was also classified as "slightly coarse." Texture is evaluated based on the granular grading presented by the muscle's outer surface when removed, as it is made up of a set of muscle fibers joined together in muscle bundles and surrounded by a tenuous layer of connective tissue known as the perimysium (MÜLLER, 1987). According to this author, texture variation is mostly associated with the animal age; young bovines produce meat with a thinner texture than older animals. However, it is presumed that the difference between the experimental animals' ages alone could not account for the change in meat texture, because the largest difference in timeframe among slaughter weights was $75 \mathrm{~d}$. In addition, there is evidence that the differences seen among the meat textures of young animal tend to disappear in adult cattle (CATTELAN et al., 2009).
The marbling of meat increased linearly with slaughter weight (Table 7), progressing from the classification "traces" at the smallest slaughter weight to "small" at the largest slaughter weight. These results are similar to those reported in the literature (COSTA et al., 2002c; ARBOITTE et al., 2004c; KUSS et al., 2005), which indicate that greater meat marbling was present at the highest slaughter weights, a phenomenon which is explained by the fact that marbling represents a later deposit of fat in the carcass (BERG; BUTTERFIELD, 1976). The increase in marbling is considerable desirable as it prevents the shortening of the muscle fibers in cold temperatures, and drip loss during cooking. In addition, increases the solubility of collagen, thus increasing meat tenderness (LI et al., 2006). Moreover, Costa et al. (2002c) found that marbling is positively correlated $(\mathrm{r}=0.56 ; \mathrm{P}=0.004)$ with palatability, indicating the presence of substances favoring palatability. In this study, the palatability of meats increased linearly $(\mathrm{P}<0.05)$ with slaughter weight, a result which may, as described above, be explained by the increase in marbling $(\mathrm{r}=0.63$; $\mathrm{P}<$ 0.0001).

Meat tenderness was not affected $(\mathrm{P}>0.05)$ by increases in slaughter weight (Table 7); it was classified, generally, as "slightly above average" (average, 6.05 points). These results are similar to 
those presented by the majority of related studies (RESTLE et al., 1996; COSTA et al., 2002c; ARBOITTE et al., 2004c), in that increasing slaughter weight was not effective in changing the shear strength of the meat's muscle fibers. Nevertheless, these results differ from those reported by Kuss et al. (2005), who determined that slaughtered animals with greater body weight produced meat with relatively less shearing strength in the muscle fibers. This was thought to be linked to the increase in marbling fat. However, in this study it was not possible to verify the presence of a correlation ( $\mathrm{r}=0.03 ; \mathrm{P}=0.430$ ) between tenderness and meat marbling; which may be associated with less meat marbling this experiment regarding by Kuss et al. (2005).

\section{Conclusions}

Increasing the slaughter weight of Purunã cows above the minimum industry requirements is not beneficial for the production system, as it decreases the efficiency of transforming feed into meat. Likewise, encouraging the production of animals with high body weights is not beneficial to the industrial sector, because the increase in slaughter weight increases the quantity of fat removed from commercial cuts; therefore, this is not very efficient in increasing the yield of meat cuts.

Although the increase in slaughter weight favors palatability, there was no effect on tenderness. Consequently, this method is desirable when there is a demand for meats with a high marbling intensity.

\section{References}

ALVES, D. D. Crescimento compensatório em bovinos de corte. Revista Portuguesa de Ciências Veterinárias, Lisboa, v. 98, n. 546, p. 61-67, 2003.

ANUÁRIO DA PECUÁRIA BRASILEIRA ANUALPEC. 21. ed. São Paulo: Instituto FNP, 2014. $303 \mathrm{p}$.
ARBOITTE, M. Z.; RESTLE, J.; ALVES FILHO, D. C.; BRONDANI, I. L.; PACHECO, P. S.; MENEZES, L. F. G.; PEROTONI, J. Composição física da carcaça, qualidade da carne e conteúdo de colesterol no músculo Longissimus dorsi de novilhos $5 / 8$ Nelore - 3/8 Charolês abatidos em três estádios de desenvolvimento. Revista Brasileira de Zootecnia, Viçosa, MG, v. 33, n. 4, p. 959968, 2004c.

ARBOITTE, M. Z.; RESTLE, J.; ALVES FILHO, D. C.; BRONDANI, I. L.; SILVA, J. H. S.; NÖRNBERG, J. L.; KUSS, F. Desempenho em confinamento de novilhos $5 / 8$ Nelore $-3 / 8$ Charolês abatidos em diferentes estádios de desenvolvimento. Revista Brasileira de Zootecnia, Viçosa, MG, v. 33, n. 4, p. 947-958, 2004a.

ARBOITTE, M. Z.; RESTLE, J.; ALVES FILHO, D. C.; PASCOAL, L. L.; PACHECO, P. S.; SOCCAL, D. C. Características da carcaça de novilhos 5/8 Nelore - 3/8 Charolês abatidos em diferentes estádios de desenvolvimento. Revista Brasileira de Zootecnia, Viçosa, MG, v. 33, n. 4, p. 969-977, 2004b.

ASSOCIATION OF OFFICIAL ANALYTICAL CHEMISTS - AOAC. Official methods of analysis. $15^{\text {th }}$ ed. Washington, D. C., 1990. 1141 p.

BAIL, C. A. T.; BRONDANI, I. L.; RESTLE, J. Níveis de concentrado na fase de terminação em confinamento para novilhos previamente mantidos em pastagem nativa ou cultivada. Ciência Rural, Santa Maria, v. 30, n. 1, p. 151-157, 2000.

BERG, R. T.; BUTTERFIELD, R. M. New concepts of cattle growth. $5^{\text {th }}$ ed. Sydney: Sydney University Press, 1976. 240 p.

BOGGS, D. L.; MERKEL, R. A. Live animal: carcass evaluation and selection manual. Iowa: Michigan State University, 1981. 199 p.

CATTELAM, J.; MENEZES, L. F. G.; FERREIRA, J. J.; RESTLE, J.; ALVES FILHO, D. C.; BRONDANI, I. L. Gorduras de descarte e componentes externos do corpo de novilhos e vacas de descarte de diferentes grupos genéticos. Ciência Rural, Santa Maria, v. 40, n. 12, p. 2541-2548, 2010.

CATTELAN, J.; MENEZES, L. F. G.; FERREIRA, J. J.; RESTLE, J.; BRONDANI, I. L.; ARBOITTE, M. Z.; PAULA, P. C. de. Composição física da carcaça e qualidade da carne de novilhos e vacas de descarte de diferentes grupos genéticos submetidos a diferentes frequências de alimentação. Ciência Animal Brasileira, Goiânia, v. 10, n. 3, p. 764-775, 2009. 
COSTA, E. C.; RESTLE, J.; BRONDANI, I. L.; PEROTTONI, J.; FATURI, C.; MENEZES, L. F. G. Composição física da carcaça, qualidade da carne e conteúdo de colesterol no músculo Longíssimus dorsi de novilhos Red Angus superprecoces, terminados em confinamento e abatidos com diferentes pesos. Revista Brasileira de Zootecnia, Viçosa, MG, v. 31, n. 1, p. 417428, 2002c. Suplemento.

COSTA, E. C.; RESTLE, J.; PASCOAL, L. L.; VAZ, F. N.; ALVES FILHO, D. C.; ARBOITTE, M. Z. Desempenho de novilhos Red Angus superprecoces, confinados e abatidos com diferentes pesos. Revista Brasileira de Zootecnia, Viçosa, MG, v. 31, n. 1, p. 129138, 2002a.

COSTA, E. C.; RESTlE, J.; VAS, F. N.; ALVES FILHO, D. C.; BERNARDES, R. A. L. C.; KUSS, F. Características da carcaça de novilhos Red Angus superprecoces abatidos com diferentes pesos. Revista Brasileira de Zootecnia, Viçosa, MG, v. 31, p. 417-428, 2002b. Suplemento.

CRANWELL, C. D.; UNRUH, J. A.; BRETHOUR, J. R.; SIMMS, D. D. Influence of steroid implants and concentrate feeding on carcass and longissimus muscle sensory and collagen characteristics of cull beef cows. Journal of Animal Science, Champaign, v. 74, n. 8, p. 1777-1783, 1996.

DI MARCO, O. N. Crescimento y respuesta animal. Buenos Aires: Associaccíon Argentina de Producción Animal, 1994. 129 p.

FONTES, C. A. A.; GUIMARÃES, R. M.; ALMEIDA, M. I. V. de; CAMPOS, O. F. de; ALMEIDA, F. Q. de; SANT'ANA, N. F. Avaliação do ganho compensatório em novilhos mestiços Holandês-Gir: consumo e desempenho. Revista Brasileira de Zootecnia, Viçosa, MG, v. 36, n. 3, p. 698-708, 2007.

JORGE, A. M.; FONTES, C. A. A.; FREITAS, J. A.; SOARES, J. E.; RODRIGUES, L. R. R.; RESENDE, F. D. de; QUEIROZ, A. C. Rendimento da carcaça e de cortes básicos de bovinos e bubalinos, abatidos com diferentes estágios de maturidade. Revista Brasileira de Zootecnia, Viçosa, MG, v. 26, n. 5, p. 1048-1054, 1997.

KUSS, F.; MENEZES, L. F. G.; OSMARI, M. P.; RESTlE, J.; PASCOAL, L. L.; SANTOS, A. P. Desempenho de vacas de descarte recebendo dietas com ou sem monensina. Ciência Rural, Santa Maria, v. 38, n. 1, p. 173-177, 2008.

KUSS, F.; RESTLE, J.; BRONDANI, I. L.; PASCOAL, L. L.; MENEZES, L. F. G.; PAZDIORA, R. D.; FREITAS, L. S. Características da carcaça de vacas de descarte de diferentes grupos genéticos terminadas em confinamento com distintos pesos. Revista Brasileira de Zootecnia, Viçosa, MG, v. 34, n. 3, p. 915-925, 2005.

LAWRENCE, T.; FOWLER, V. Growth of farm animals. London: CAB International, 2005. $330 \mathrm{p}$.

LI, C.; ZHOU, G.; XU, X.; ZHANG, J.; XU, S.; JI, Y. Effects of marbling on meat quality characteristics and intramuscular connective tissue of beef Longissimus muscle. Asian-Australian Journal Animal Science, Seoul, v. 12, n. 19, p. 1719-1808, 2006.

MISSIO, R. L.; RESTLE, J.; MOLETTA, J. L.; KUSS, F.; NEIVA, J. N. M.; MOURA, I. C. F. Características da carcaça de vacas de descarte abatidas com diferentes pesos. Revista Ciência Agronômica, Fortaleza, v. 44, n. 3, p. 644-651, 2013a.

MISSIO, R. L.; RESTLE, J.; MOLETTA, J. L.; KUSS, F.; NEIVA, J. N. M.; MIOTTO, F. R. C.; PRADO, I. N.; ELEJALDE, D. A. G.; PEROTTO, D. Componentes do corpo vazio de vacas da raça Purunã abatidas com pesos distintos. Semina Ciências Agrárias, Londrina, v. 44, n. 3, p. 644-651, 2013b.

MOURA, I. C. F.; KUSS, F.; MOLETTA, J. L.; PEROTTO, D.; STRACK, M. G.; MENEZES, L. F. G. de. Terminação em confinamento de vacas de descarte recebendo dietas com diferentes teores de concentrado. Semina: Ciências Agrárias, Londrina, v. 34, n. 1, p. 399408, 2013.

MÜLLER, L. Normas para a avaliação de carcaças e concurso de carcaças de novilhos. 2. ed. Santa Maria: Universidade Federal de Santa Maria, 1987. 31 p.

NATIONAL RESEARCH COUNCIL - NRC. Nutrients requirements of beef cattle. $7^{\text {th }}$ ed. Washington, D. C., 1996. $242 \mathrm{p}$.

RESTLE, J.; BRONDANI, I. L.; ALVES FILHO, D. C.; BERNARDES, R. A. C.; NEUMANN, M.; FATURI, C.; PACHECO, P. Efeito do grupo genético e heterose na terminação de vacas de descarte em confinamento. Revista Brasileira de Zootecnia, Viçosa, MG, v. 30, n. 2, p. 374-382, 2001b.

RESTLE, J.; KEPLIN, L. A. S.; VAZ, F. N. Desempenho em confinamento de novilhos Charolês, abatidos com diferentes pesos. Pesquisa Agropecuária Brasileira, Brasília, v. 32, n. 8, p. 857-860, 1997.

RESTLE, J.; KEPLIN, L. A. S.; VAZ, F. N.; MÜLLER, L. Qualidade da carne de novilhos Charolês confinados e abatidos com diferentes pesos. Ciência Rural, Santa Maria, v. 26, n. 3, p. 463-466, 1996. 
RESTLE, J.; LUPATINI, G. C.; ROSO, C.; SOARES, A. B. Eficiência e desempenho de categorias de bovinos de corte em pastagem cultivada. Revista Brasileira de Zootecnia, Viçosa, MG, v. 27, n. 2, p. 397-404, 1998.

RESTLE, J.; NEUMANN, M.; ALVES FILHO, D. C.; PASCOAL, L. L.; ROSA, J. R. P.; MENEZES, L. F. G. de; PELLEGRINI, L. G. de. Terminação em confinamento de vacas e novilhas sob dietas com ou sem monensina sódica. Revista Brasileira de Zootecnia, Viçosa, MG, v. 30, n. 6, p. 1801-1812, 2001a.

SNIFFEN, C. J.; O’CONNOR, J. D.; VAN SOEST, P. J.; FOX, D. G.; RUSSEL, J. B. A net carbohydrate and protein system for evaluating cattle diets: II. Carbohydrate and protein availability. Journal of Animal Science, Champaign, v. 70, n. 12, p. 3562-3577, 1992.

VAN SOEST, P. J. Collaborative study of acid-detergent fiber and lignin. Journal of the Association of Official Analytical Chemists, Pennsylvania, v. 56, p. 781-784, 1973.
VAN SOEST, P. J.; ROBERTSON, J. B.; LEWIS, B. A. Methods for dietary fiber, neutral detergent fiber, and nonstarch polysaccharides in relation to animal nutrition. Journal of Animal Science, Champaign, v. 74, n. 10, p. 3583-3597, 1991.

VAZ, F. N.; RESTlE, J.; ARBOITTE, M. Z.; PASCOAL, L. L.; ALVES FILHO, D. C.; PACHECO, R. F. Características de carcaça e da carne de novilhos e novilhas superjovens, terminados com suplementação em pastagem cultivada. Ciência Animal Brasileira, Goiânia, v. 11, n. 1, p. 42-52, 2010.

VAZ, F. N.; VAZ, R. Z.; PASCOAL, L. L.; PACHECO, P. S.; MIOTTO, F. R. C.; TEIXEIRA, N. P. Análise econômica, rendimentos de carcaça e dos cortes comerciais de vacas de descarte $5 / 8$ Hereford $3 / 8$ Nelore abatidas em diferentes graus de acabamento. Ciência Animal Brasileira, Goiânia, v. 13, n. 3, p. 338-345, 2012.

WEISS, W. P. Method estimates available energy value for ruminants. Feedstuffs, New York, v. 9, p. 13-14, 1993. 
